\title{
Food safety knowledge, attitudes and practices of street food vendors in Jashore region, Bangladesh
}

\author{
Md. Toufik HOSSEN ${ }^{1}$, Md. Jannatul FERDAUS ${ }^{1}$ (D), Md. Mohibul HASAN ${ }^{1}$, Nazia Nawshad LINA ${ }^{1}$, \\ Ashish Kumar DAS ${ }^{2}$, Shital Kumar BARMAN ${ }^{3}$ (D), Dipak Kumar PAUL ${ }^{4}$, Rajib Kanti ROY ${ }^{1,4 *}$ (])
}

\begin{abstract}
Most people now have their meals outside their homes and are vulnerable to illness caused by food. Unsafe food preparation and supply by vendors have made food safety a concern for public health. Jashore is a densely populated city, this study was designed to evaluate food safety knowledge, attitude and practice (KAP) of food vendors in Jashore region, Bangladesh. A randomized descriptive cross-sectional study on food safety KAP was conducted among 200 food vendors. Where $96 \%$ were male food vendors, $72.5 \%$ were smokers, and $63 \%$ were found to be overweight or obese. While $72.5 \%$ vendors had good knowledge of food safety, only $33 \%$ and $0.5 \%$ had good food safety attitude and practice, respectively. Among the socio-demographic factors investigated, only the level of education showed significant influence ( $\mathrm{p}=0.005$ and 0.015$)$ on the food safety knowledge and practice of the vendors. While handling food, over $90 \%$ vendors did not use any personal protective equipment, $4.5 \%$ had diarrhoea, $8.5 \%$ did not wash their hands after going to the toilet and $28.5 \%$ reused previous leftover oils. The data suggest that the overall food safety knowledge of suppliers in the Jashore region is good but their attitudes and practices need to be improved.
\end{abstract}

Keywords: street food; food safety; hygiene; food control; food borne illness.

Practical Application: Increasing the food safety knowledge, attitudes and practices of street food vendors to reduce the foodborne diseases.

\section{Introduction}

Street food (SF) and beverages are ready-to-eat food items prepared and sold by vendors in different public places especially in streets and crowded bus or train stations in Bangladesh as well as other countries around the world (Food and Agriculture Organization of the United Nations, 2013; Winarno \& Alain, 1991). $\mathrm{SF}$ is an age-old practice and earning source of income in several countries (Cortese et al., 2016). Worldwide increase of unemployment and poverty are the key factors behind people tend to run street food businesses, because it requires minimal experience and capital to set up (Addo-Tham et al., 2020; King et al., 2000). It plays a vital socio-economic role by providing food and nutritional supports to the lower and middle-income people at a reasonably low price and is valued for the unique taste of its food items (Khairuzzaman et al., 2014). It is a typical food culture; due to the pricing of street food it is easily accessible to everyone (Lucca \& Torres, 2006). At the same time, due to their current hectic lifestyle, people have to depend on street foods as they are too busy to spend at home (Temeche et al., 2016). At the same time, street foods offer a pleasant diet for many consumers and help low-income people's livelihoods with contributions to the economy. (Al Mamun et al., 2013; Anandhi et al., 2015; König et al., 2010). Around 2.5 billion people worldwide consume street foods per day (Fellows \& Hilmi, 2011).
Street food safety is a critical public health issue in the third world and developing countries, including Bangladesh. (Khairuzzaman et al., 2014; Muinde \& Kuria, 2005; Samapundo et al., 2016). In those countries, street food is an important source of food for the urban dwellers and the concerns about street food are the safety, nutritional value, vendor's knowledge of food hygiene and the ineffectiveness of safety legislations (Hiamey \& Hiamey, 2018). In Bangladesh, street vendors are typically clustered in overcrowded areas including residential areas, near the workplaces, taxi ranks, railway stations and busy street pavements due to the hope of mass sales (Gamieldien \& van Niekerk, 2017). People of all ages from different backgrounds consume these food items as these are inexpensive, convenient and comparatively nutritious (Lues et al., 2006).

Foodborne diseases are a significant and growing public health problem in both developing and developed countries (Bhattacharjya \& Reang, 2014). Food items are contaminated with microorganisms, can result in a foodborne disease outbreak (Webb \& Morancie, 2015). Several previous studies have indicated that a large proportion of street foods are contaminated with microorganisms and can cause diseases such as diarrhoea, cholera, typhoid fever and food poisoning (Al Mamun et al., 2013; Oguttu et al., 2014). Consumption of contaminated 
food and water causes the death of about 2 million people per year, most of whom are children (World Health Organization, 2014). In general, food items from the street food vendors are processed and distributed in unsafe conditions, with less access to safe water, sanitation or waste disposal facilities. There is widespread recognition in developing countries that street food vendors frequently cook and sell food under unhygienic conditions (Sharma \& Mazumdar, 2014). Additionally, they are often uneducated and have little knowledge about the safe handling of foods (Lues et al., 2006). Several studies have reported that the street food items are an appropriate medium for coliforms and antimicrobial-resistant pathogens despite their diversity and temporary nature (Ghosh et al., 2007; Guven et al., 2010; Hanashiro et al., 2005; Harakeh et al., 2005). Consequently, foodborne infections and intoxications can occur from the intake of food products from the street, rendering the safety of street food a significant public health concern (Bryan, 1988; Ekanem, 1998; Rheinländer et al., 2008; Sharma \& Mazumdar, 2014).

In south-east Asia, especially Bangladesh is particular for its cheap and diversified street food items, vendors prepare their food items manually and sell to the consumers at various crowded places (Al Mamun et al., 2013; Samapundo et al., 2016). Due to rapid urbanization and its related social and systemic changes, demands for street food in Bangladesh are growing day by day, despite the health problems associated with the selling of various types of street food items. It has been shown that there are approximately 130 forms of street food items are available in Bangladesh and about 2.5 million people eat street food every day (Food and Agriculture Organization of the United Nations, 2007). None of these food items have any guarantee for their safe consumption. Also, interestingly, people do not consume these food items to satisfy their appetite, instead consider them as nutritious and appealing (Islam et al., 2017). Children who go to school eat these unhealthy foods and get sick (Al Mamun et al., 2013). The low level of awareness and vulnerability of current food laws and regulations also lead to the adverse food safety situation in the country (Atahar Ali, 2013). Only a few developing countries have their national laws to regulate their food safety, where developed world like EU (European Union) applies HACCP principles or good safety practices through the skilled food safety authority (Food and Agriculture Organization of the United Nations, 2003; Trafialek et al., 2018).

In Bangladesh, relatively few studies have been performed on the awareness, attitudes and experience of vendors in food safety (Khairuzzaman et al., 2014). Besides, some of the most popular ready-to-eat food products sold on the streets in Jashore are highly contaminated and do not meet the necessary standards quality and safety levels (Hossain \& Dey, 2019). The current research focusing exclusively on the street food vendors' KAP was conducted in the Jashore region which is one of the socioeconomically significant regions of Bangladesh (Bangladesh Bureau of Statistics, 2017) with numerous and wide variety of street foods sold there as well. So, undertaking this study will determine the present scenario of street food safety in the studied region and may help the food safety authorities to improve their food safety programs. Furthermore, from a related sociodemographic viewpoint, the current study could help other similar studies to evaluate food safety challenges at the national and global levels.

This study was therefore investigated into the knowledge, attitude and practice of food safety and hygiene among local street vendors in the Jashore area and thus suggest appropriate steps to reduce the threats of related foodborne diseases to improve public health at local and national levels.

\section{Materials and methods}

This randomized cross-sectional study was conducted to investigate the awareness, behaviours and activities of street food vendors (SFVs) and evaluate sociodemographic factors that are associated with these food safety parameters in the Jashore region of Bangladesh. Data were randomly collected from the vendors $(n=200)$ through a structured questionnaire from April 2019 to September 2019. Due to its overpopulation and a large number of street food vendors, the district was chosen as a study area. The research was conducted in three zones; rural, urban, and slum. The protocols adopted for carrying out each analysis are listed in more detail below. Figure 1 shows the location of the studied area.

\subsection{Food safety knowledge, attitudes and practices questionnaire}

During the field survey, data from the 200 street vendors were obtained via face-to-face questioning, which facilitated to understand the realistic scenario of the current study. The questionnaires were divided into two sections, one was the food safety KAP and another was the demographic information as previously described (Ngoc et al., 2011). The KAP's part of

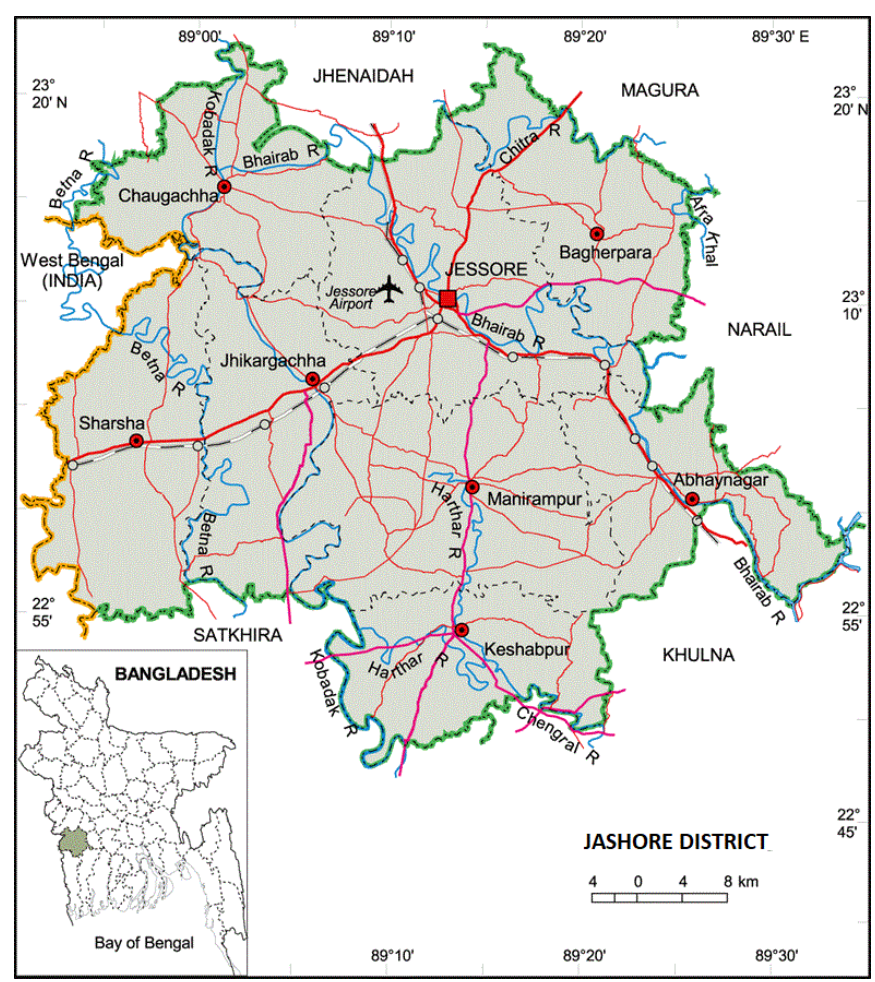

Figure 1. The study area. Source: Maps of Bangladesh (2012). 
the questionnaire used to assess the food safety knowledge, attitudes and practices of the street food vendors was according to the previously published procedure (Ansari-Lari et al., 2010). The questions were asked in the mother tongue "Bengali" and the responses were translated into the English language. Subsequently, data were triangulated to present an overall impression of the food vendor's healthy practice, as shown previously (Cortese et al., 2016). The socio-demographic part of the questionnaire was designed to collect data on food handlers' age, gender, civil status, smoking status, education level, monthly income, residence area and so on. The questionnaire on food safety knowledge was intended to obtain information on the experience of food handlers' awareness of food handling, personal hygiene, cross contamination, cleaning equipment and, packaging materials etc. It included 21 questions, each with two possible answers. To reduce the response bias, the multiple-choice answers included "yes \& no" options (yes $=1 \&$ no $=0$ ). The score range was 0 to 21 . Part II included 21 questions related to food handlers' attitudes toward food safety. Food handlers were asked to indicate their level of agreement to the statements using a three-point rating scale $(2=$ strongly agree, $1=$ agree and, $0=$ disagree $)$. The score range was 0 to 42 . The scores were converted to 100 points. Part III of the questionnaire consisted of a list of 23 practices that would indicate food handlers' practice. A five points rating scale ( 2 = always, $1=$ sometimes, $0=$ never $)$ was used for respondents to rate the level of impact of each practice. The score range was between 0 to 46 . Subsequently, the KAP scores were converted to 100 points. The score $<50$ was considered as indicating a poor, scores 50 to 75 as a median (adequate), and scores $>75$ as a good food safety knowledge, attitude, and practice level, respectively.

\subsection{Statistical analysis method}

The results of the survey were collected in excel sheets and analysed using statistical package for the social sciences (SPSS version 22.0) to identify the key factors and major impediments of ensuring food safety by the street vendors. Descriptive statistics to summarize the variables of interest and determine correlations between were applied. Statistical significance at $95 \%$ confidence level was considered $(\mathrm{P} \leq 0.05)$. The age, experience, BMI (Body Mass Index) and score results were divided into different categories as follows. For descriptive analysis, cut-off points of age were $<25,25$ to 50 and $>50$ years. For respondents' experience of vending the cut of points were $<5,5$ to 9,10 to 15 and $>15$ years. The cut off points of BMI of the food vendors were $<17.5 \mathrm{Kg} / \mathrm{m}^{2}$ (Underweight), 17.5 $22.99 \mathrm{Kg} / \mathrm{m}^{2}$ (Normal weight), $23-27.99 \mathrm{Kg} / \mathrm{m}^{2}$ (Overweight) and $>28 \mathrm{Kg} / \mathrm{m}^{2}$ (Obese) (World Health Organization, 2004). Descriptive analyses were conducted to calculate the means, standard deviations, maximum and minimum values, and KAP scores based on different socio-demographic variables of the respondents. The following performed a comparison of the level of scores according to the socio-demographic characteristics by chi-square test. Independent samples t-testing conducted a comparison of two community variables such as gender and smoking with awareness, attitude or practice. Comparison of more than two groups such as age, area of residence and level of education were conducted by employing one-way ANOVA. The normality of the data was first tested by using the explorer test. Instead, through the use of square root transformation of data, the negatively skewed scores were converted to the form of normal distribution. Figure 2 represents the flowchart of the methodology.

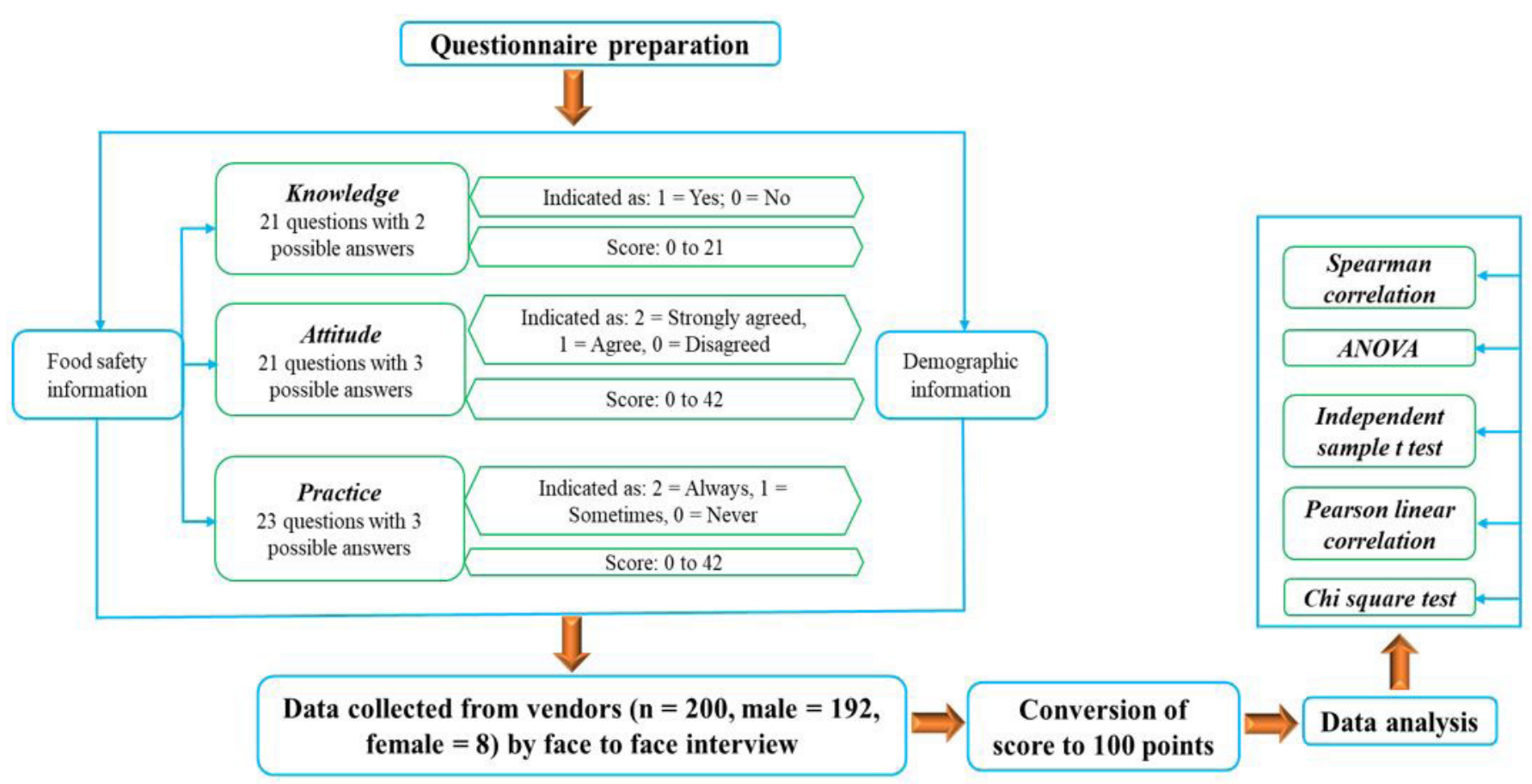

Figure 2. Methodological overview of the study. 


\section{Results}

\subsection{Socio-demographic characteristics of food vendors in Jashore.}

In Table 1 are shown the socio-demographic characteristics of street food vendors, which shows that most (96\%) of the 200 respondents were male vendors and $91.5 \%$ married. Where we found $70.5 \%(n=141)$ vendor's age between 25 and 50 years. About $37.5 \%$ vendors had 5 to 9 years of vending experience, while $8.5 \%$ had more than 20 years' experience. Most of the vendors (43\%) monthly income were between 5,000 and 10,000 BDT ( $\$ 58.98$ to $\$ 117.97$ ) while $7 \%$ vendors earned as low as 5,000 BDT only (>\$58.98). Disturbingly, more than two-

Table 1. Socio-demographic characteristics of food vendors.

\begin{tabular}{|c|c|c|}
\hline Characteristics & Frequency & Percentage (\%) \\
\hline \multicolumn{3}{|l|}{ Gender } \\
\hline Male & 192 & 96 \\
\hline Female & 8 & 4 \\
\hline \multicolumn{3}{|l|}{ Age (year) } \\
\hline$<25$ & 38 & 19 \\
\hline 25 to 50 & 141 & 70.5 \\
\hline$>50$ & 21 & 10.5 \\
\hline \multicolumn{3}{|l|}{ Vending experience (year) } \\
\hline$<5$ & 54 & 27 \\
\hline $5-9$ & 75 & 37.5 \\
\hline $10-20$ & 54 & 27 \\
\hline$>20$ & 17 & 8.5 \\
\hline \multicolumn{3}{|l|}{ Education level } \\
\hline Illiterate & 55 & 27.5 \\
\hline Primary (class 1-5) & 94 & 47 \\
\hline Secondary (class 6-10) & 44 & 22 \\
\hline Higher (over 10) & 7 & 3.5 \\
\hline \multicolumn{3}{|l|}{ Monthly income (BDT) } \\
\hline$<5000$ & 14 & 7 \\
\hline $5000-10000$ & 86 & 43 \\
\hline $10001-15000$ & 77 & 38.5 \\
\hline$>15000$ & 23 & 11.5 \\
\hline \multicolumn{3}{|l|}{ Marital status } \\
\hline Single & 16 & 8 \\
\hline Married & 183 & 91.5 \\
\hline Widow & 1 & 0.5 \\
\hline \multicolumn{3}{|l|}{ Residence area } \\
\hline Rural & 96 & 48 \\
\hline Urban & 92 & 46 \\
\hline Slum & 12 & 6 \\
\hline \multicolumn{3}{|l|}{ Smoking status } \\
\hline Yes & 145 & 72.5 \\
\hline No & 55 & 27.5 \\
\hline \multicolumn{3}{|l|}{$\operatorname{BMI}\left(\mathrm{Kg} / \mathrm{m}^{2}\right)$} \\
\hline Underweight $(<17.5)$ & 4 & 2 \\
\hline Normal weight (17.5 -22.99) & 70 & 35 \\
\hline Overweight (23-27.99) & 105 & 52.5 \\
\hline Obese $(>28)$ & 21 & 10.5 \\
\hline Total & 200 & \\
\hline
\end{tabular}

Note: $\mathrm{BMI}=$ Body Mass Index, BDT $=$ Bangladeshi Taka $(1 \mathrm{USD}=84.83$ BDT $)$. thirds (72.5\%) of the respondents were smoker. Approximately, an equal proportion of vendors were from rural (48\%) and urban $(46 \%)$ regions respectively, whereas $6 \%$ vendors lived in the slum areas. Based on the BMI assessment of health, we also observed $52.5 \%$ and $10.5 \%$ respondents were overweight and obese, respectively.

\subsection{Food safety knowledge of food vendors in Jashore}

The knowledge about the food safety in street food vendors is presented in Table 2. In order to preserve personal hygiene, $100 \%$ of the surveyed vendors strongly believed in hand washing before work, while $96 \%$ believed in hand washing after work. $91.55 \%(n=183)$ had the awareness that washing hands could adequately reduce the risk of contamination, while $8.5 \%(\mathrm{n}=17)$ felt that washing hands could not effectively reduce the risk of contamination with food handling. $94 \%$ $(\mathrm{n}=188)$ knew that only water could not clean hand properly. Surprisingly, about one-fourth of the vendors did not know that personal protective equipment such as apron, mask, gloves, and caps are the parts of personal hygiene. A good number of vendors (73\%) were aware of not touching their hair after washing hands. According to our study findings, $94.5 \%$ of vendors knew that proper cleaning and handling of instruments reduce the risk of food contamination, whereas 91.5\% ( $\mathrm{n}=183$ ) were informed about cleaning equipment after work can reduce cross-contamination. Besides, $80.5 \%$ $(n=161)$ were aware that their long nails could contaminate food. Moreover, $79.5 \%(n=159)$ of vendors knew that reusing of oil is dangerous to health and less than half (48.5\%) of the vendors had knowledge about paper/polythene packs are unsafe for food packaging.

The scores of food safety knowledge of vendors as an act of their demographic characteristics are summarized in Table 3. Most of the food vendors $(72.5 \%, 145 / 200)$ had enough knowledge about food safety as they scored $\geq 75$ and only $7 \%(14 / 200)$ had insufficient knowledge scored $<50$. According to this study, only street food vendors' education had a significant $(\mathrm{p} \leq 0.01)$ influence on their knowledge of food safety and no significant differences were observed with respect to gender, age, year of experience, monthly income, civil status, residence area, smoking and BMI. $87.5 \%$ of the female and about $72 \%$ of male vendors belonged to a good category of food safety knowledge. The highest $81.5 \%$ of the vendors experienced 10 to 20 years of vending had a good food safety knowledge, followed by $76.5 \%$ of the vendors vending for $>20$ years were within the good category of food safety knowledge.

\subsection{Food safety attitudes of street food vendors in Jashore city}

The food safety attitudes of the suppliers studied are shown in Table 4. All food vendors agreed to food safety knowledge would benefit their personal lives, of which $60.5 \%$ $(\mathrm{n}=121)$ strongly agreed. Where $1 \%(2 / 200)$ did not agree with safe food handling is an important part of their job responsibility. All food vendors agreed with good personal hygiene and washing hand prior to food handling can reduce food poisoning and foodborne illness. Moreover, $10.5 \%$ of 
Table 2. Assessment of the Food safety knowledge of food vendors.

\begin{tabular}{|c|c|c|c|c|}
\hline Statement & $\begin{array}{c}\text { Yes } \\
\mathrm{n}(\%)\end{array}$ & $\begin{array}{c}\text { No } \\
\mathrm{n}(\%)\end{array}$ & p- value & $\begin{array}{l}\mathrm{Chi}^{2}- \\
\text { value }\end{array}$ \\
\hline 1. Washing hands regularly before work is one part of personal hygiene. & $200(100)$ & 0 & 0.00 & ---- \\
\hline 2. Washing hands regularly after work is one part of personal hygiene. & $192(96)$ & $8(4)$ & 0.00 & 353.71 \\
\hline 3. Washing hands properly reduces risk of food contamination. & $183(91.5)$ & $17(8.5)$ & 0.00 & 304.57 \\
\hline 4. Washing hands with only water can't clean enough. & $188(94)$ & $12(6)$ & 0.00 & 331.27 \\
\hline 5. Wearing apron, mask, gloves, and caps is one part of personal hygiene. & $150(75)$ & $50(25)$ & 0.00 & 156.37 \\
\hline 6. Wearing mask is one part of personal hygiene. & $151(75.5)$ & $49(24.5)$ & 0.00 & 160.09 \\
\hline 7. Wearing gloves is one part of personal hygiene. & $159(79.5)$ & $41(20.5)$ & 0.00 & 191.89 \\
\hline 8. Wearing cap is one part of personal hygiene. & $157(78.5)$ & $43(21.5)$ & 0.00 & 183.37 \\
\hline 9. Workers should avoid touching their hair after washing hands. & $146(73)$ & $54(27)$ & 0.00 & 141.88 \\
\hline 10. Eating and drinking in the workplace increase the risk of food contamination. & $122(61)$ & $78(39)$ & 0.00 & 75.64 \\
\hline 11. Proper cleaning and handling of instruments reduce the risk of food contamination. & $189(94.5)$ & $11(5.5)$ & 0.00 & 336.79 \\
\hline 12. Worker cannot have long nails and make colouring it. & $161(80.5)$ & $39(19.5)$ & 0.00 & 202.93 \\
\hline 13. Use gloves reduces the risk of transmitting infection to consumers. & $148(74)$ & $52(26)$ & 0.00 & 149.92 \\
\hline 14. Broken gloves need to be changed with new ones. & $160(80)$ & $40(20)$ & 0.00 & 197.47 \\
\hline 15. Cleaning equipment after work can reduce cross contamination. & 183(91.5) & $17(8.5)$ & 0.00 & 304.57 \\
\hline 16. Using hot water to clean equipment still decrease risk of contamination. & $151(75.5)$ & $49(24.5)$ & 0.00 & 160.63 \\
\hline 17. Separating dirty zone from clean zone can reduce cross contamination. & $146(73)$ & $54(27)$ & 0.00 & 142.46 \\
\hline 18. Contaminated foods always have some change in colour, odour or taste. & $168(84)$ & $31(16)$ & 0.00 & 232.96 \\
\hline 19. Reuse of oil is dangerous for health. & 159(79.5) & $41(20.5)$ & 0.00 & 197.29 \\
\hline 20. Reheating cooked foods can contribute to food contamination. & $104(52)$ & $96(48)$ & 0.00 & 32.44 \\
\hline 21. Paper/polythene packs are unsafe for food packaging. & $97(48.5)$ & $103(51.5)$ & 0.00 & 23.41 \\
\hline
\end{tabular}

Note: $\mathrm{n}=$ Number of vendors, $\mathrm{p}=$ Significance value.

food vendors denied producing safe food than made it tasty. Only $8.5 \%$ of the food vendors dissented with not to touch food with wounded hands. In addition, $11 \%(n=22)$ of food vendors disagreed with not rubbing hands on the face or hair while working. Unexpectedly, $6 \%(\mathrm{n}=12)$ did not know that foodborne illnesses can have deleterious health and economic effects on society. Almost one-fourth $(n=43)$ of the vendors had no idea that cooked food could be contaminated when stored together with raw food. Besides, we also found that about $27 \%(n=55)$ of food vendors disagreed with the safety of polythene and paper bags in food packaging.

Table 5 summarizes the food safety attitudes of the vendors. In male and female vendors, $33.3 \%$ and $25 \%$ belonged to the good category of food safety attitude, respectively. Significant differences $(p \leq 0.05)$ between food vendors in their food safety attitudes were observed by the area of residence and BMI, while other factors did not show a significant impact on the vendor's food safety attitudes. The duration of the vending years was not significant $(\mathrm{p}=0.322)$ with their attitude towards food safety. A majority (49\%) of the food vendors scored at a moderate attitude level of food safety whereas about one third (33\%) scored at a good attitude level of food safety. In addition, range indicates that vendors individually achieved a minimum 30.95 and a maximum 100 food safety attitude score.

\subsection{Food safety practice of street food vendors in Jashore city}

Table 6 demonstrates the food safety practices of food vendors. $86 \%$ of the street food vendors reported washing their hands always before processing of foods. 49 percent $(n=98)$ of vendors always washed their hands before touching unwrapped raw food, while 49.5 percent sometimes and the rest never washed their hands. About 50\% respondents always washed their hands after touching unwrapped raw foods while 33.5\% sometimes did. Only 54\% respondents kept their nails short and removed all adornments before starting activities regularly. During the observation, we found $58 \%$ food vendors washed their hands after touching prepared food. $4.5 \%$ food handlers worked when they had diarrhoea, while $72.5 \%$ cleaned the work area before starting work. This study also found that a good number of vendors $(78.5 \%)$ washed their hands using soap or detergent after going to the toilet. Besides, over $90 \%$ vendors did not use apron, mask, cap and gloves during work. Disappointingly, when they were coughing or sneezing, just $18 \%$ used a tissue. Just below half ( $48 \%)$ of the vendors washed and sanitized their knife after chopping raw foods, where $59 \%$ used detergent to clean their equipment. Moreover, $42.5 \%$ of food handlers never rubbed their hands on their face and hair while working and $28.5 \%$ always reused oil.

The food safety activity ratings of the vendors as a function of their socio-demographic characteristics are summarized in Table 7 . About $75 \%$ of male and female vendors belonged to the poor category of food safety practice. Interestingly we found that vendors below 25 years and over 50 years of age did not have good hygiene practice while one vendor aged 25-50 years had good practice status. We found their mean score was all about same and age was not significant to mean score of practice $(\mathrm{p}=0.558)$. According to the years of vending experience, there was only one vendor who had good food safety practice. We 
Hossen et al.

Table 3. Effect of gender, age, education level, residence area, smoking and BMI on the food safety knowledge of food vendors.

\begin{tabular}{|c|c|c|c|c|c|c|c|}
\hline \multirow[b]{2}{*}{ Characteristics } & \multicolumn{3}{|c|}{ Number of respondents (\%) } & \multirow[b]{2}{*}{$\mathrm{p}^{\dagger}$-value } & \multirow[b]{2}{*}{ Mean \pm SD } & \multirow[b]{2}{*}{$\begin{array}{c}\mathrm{p}- \\
\text { value }\end{array}$} & \multirow[b]{2}{*}{ Range } \\
\hline & $\begin{array}{l}\text { Poor } \\
(<50)\end{array}$ & $\begin{array}{c}\text { Medium } \\
(\geq 50 \text { to }<75)\end{array}$ & $\begin{array}{l}\text { Good } \\
(\geq 75)\end{array}$ & & & & \\
\hline \multicolumn{8}{|l|}{ Gender } \\
\hline Female & 0 & $1(12.5)$ & $7(87.5)$ & 0.57 & $82.73 \pm 6.70$ & $0.727^{\ddagger}$ & $71.43-90.48$ \\
\hline \multicolumn{8}{|l|}{ Age (years) } \\
\hline$>50$ & $1(4.8)$ & $4(19.0)$ & $16(76.2)$ & 0.66 & $81.63 \pm 13.65$ & $0.127^{¥}$ & $47.62-100$ \\
\hline \multicolumn{8}{|l|}{ Vending experience (year) } \\
\hline$<5$ & $3(5.6)$ & $13(24.1)$ & $38(70)$ & \multirow{3}{*}{0.406} & $77.77 \pm 14.21$ & \multirow{3}{*}{$.190^{¥}$} & $42.86-100$ \\
\hline $5-9$ & $7(9.3)$ & $18(24)$ & $50(66.7)$ & & $77.26 \pm 16.13$ & & $42.86-100$ \\
\hline $10-20$ & $4(7.4)$ & $6(11.1)$ & $44(81.5)$ & & $80.24 \pm 13.85$ & & $42.86-100$ \\
\hline Secondary & $0(0)$ & $1(2.3)$ & $43(97.7)$ & \multirow{2}{*}{$0.005^{\star *}$} & $87.55 \pm 7.83$ & \multirow{2}{*}{$0.005^{\star x}$} & $57.14-100$ \\
\hline Higher & $0(0)$ & $0(0)$ & $7(100)$ & & $94.55 \pm 5.78$ & & $85.71-100$ \\
\hline \multicolumn{8}{|l|}{ Monthly income (BDT) } \\
\hline$<5000$ & $8(7.2)$ & $3(21.4)$ & $10(71.4)$ & \multirow{4}{*}{0.673} & $79.25 \pm 15.12$ & \multirow{4}{*}{$.846^{¥}$} & $42.86-100$ \\
\hline 5000-10000 & $9(10.5)$ & $18(20.9)$ & $59(68.6)$ & & $77.68 \pm 15.94$ & & $42.86-100$ \\
\hline $10001-15000$ & $3(3.9)$ & $17(22.1)$ & $57(74)$ & & $79.53 \pm 13.94$ & & $42.86-100$ \\
\hline$>15000$ & $1(4.3)$ & $3(13)$ & $19(82.6)$ & & $81.15 \pm 12.22$ & & $47.62-100$ \\
\hline \multicolumn{8}{|l|}{ Civil status } \\
\hline Single & $1(6.2)$ & $3(18.8)$ & $12(75)$ & \multirow[b]{2}{*}{0.414} & $79.46 \pm 14.72$ & \multirow[b]{2}{*}{.816} & $47.62-100$ \\
\hline Married & $13(7.1)$ & $37(20.2)$ & $133(72.7)$ & & $78.89 \pm 14.75$ & & $42.86-100$ \\
\hline No & $4(8.9)$ & $9(20)$ & $32(71.1)$ & 0.85 & $79.25 \pm 15.76$ & 0.085 & $42.86-100$ \\
\hline BMI & & & & & & & \\
\hline Under weight & $1(25)$ & $0(0)$ & $3(75)$ & & $75.00 \pm 21.42$ & & $42.86-85.71$ \\
\hline Normal weight & $3(4.3)$ & $16(22.9)$ & $51(72.9)$ & & $80.06 \pm 13.88$ & $0534^{*}$ & $42.86-100$ \\
\hline Over weight & $8(7.6)$ & $20(19)$ & $77(73.3)$ & 0.65 & $79.04 \pm 14.76$ & $0.534^{-1}$ & $42.86-100$ \\
\hline Obese & $2(9.5)$ & $5(23.8)$ & $14(66.7)$ & & $75.05 \pm 16.00$ & & $42.86-95.24$ \\
\hline Total & $14(7)$ & $41(20.5)$ & $145(72.5)$ & & $78.90 \pm 14.68$ & & $42.86-100$ \\
\hline
\end{tabular}

Note: $\mathrm{SD}=$ Standard deviation, $\mathrm{p}=$ Significance value, BMI = Body Mass Index; BDT = Bangladeshi Taka $(1 \mathrm{USD}=84.83$ BDT $)$; ${ }^{\text {} S i g n i f i c a n c e ~ v a l u e s ~ b y ~ C h i-s q u a r e ~ t e s t ; ~}{ }^{{ }^{*}}$ Significance values by one-way ANOVA; ${ }^{\star}$ Significance values by independent sample "t" test; ${ }^{\star}$ Tests significant at $\mathrm{p} \leq 0.01$.

found that $82.4 \%$ of the vendors had poor food hygiene practice despite having more than 20 years of experience. There was only one primary educated vendor, who had good score on food safety practice. Higher educated vendors had lowest poor food safety practice level and highest mean of food safety practice score than that of illiterate, primary and secondary passed vendors. The degree of education had significance $(\mathrm{p}=0.015)$ on food safety practice of vendors. Vendors who earned more than $15,000 \mathrm{BDT}, 78.3 \%(\mathrm{n}=18)$ of them had poor hygiene practice, where $1.3 \%$ of the vendors whose monthly income was between 10,001 and 15,000 BDT had good food safety practice. We found one married vendor had good practice and there was only one widow who scored poor level of practice. Among the vendors living in the urban area, $80.4 \%$ of them had poor hygiene practice while $1.1 \%$ had good hygiene score. In addition, $33.3 \%$ of slum area vendors had medium level of food safety practice. Vendors who had smoking habit, $74.8 \%$ of them had bad hygiene practice and $77.8 \%$ of non-smokers had poor scores. Moreover, $90.5 \%$ of obese vendors had poor food safety practice and only $1 \%$ of overweight vendors had good hygiene practice. Furthermore, the minimum and maximum 
Table 4. Assessment of Food safety attitude of food vendors.

\begin{tabular}{|c|c|c|c|c|c|}
\hline Statements & $\begin{array}{l}\text { Strongly Agree } \\
\mathrm{n}(\%)\end{array}$ & $\begin{array}{l}\text { Agree } \\
\mathrm{n}(\%)\end{array}$ & $\begin{array}{c}\text { Disagree } \\
\mathrm{n}(\%)\end{array}$ & $\begin{array}{c}\mathrm{p}- \\
\text { value }\end{array}$ & $\begin{array}{l}\mathrm{Chi}^{2}- \\
\text { value }\end{array}$ \\
\hline 1. Food safety knowledge will benefit to personal life. & $121(60.5)$ & $79(39.5)$ & 00 & 0.00 & 8.82 \\
\hline 2. Food safety knowledge will benefit to consumers. & $103(51.5)$ & $97(48.5)$ & 00 & 0.67 & 0.18 \\
\hline 4. Good personal hygiene can prevent foodborne illness. & $82(41)$ & $118(59)$ & 00 & 0.00 & 6.48 \\
\hline 5. Washing hands before handling food reduces risk of food poisoning. & $99(49.5)$ & $101(50.5)$ & 00 & 0.01 & 97.09 \\
\hline 8. Food should not be touched with wounded hands. & $84(44)$ & $95(47.5)$ & $17(8.5)$ & 0.00 & 55.87 \\
\hline 9. Reuse of oil is harmful for health. & $121(60.5)$ & $59(29.5)$ & $20(10)$ & 0.00 & 77.83 \\
\hline 10. Should not rub your hand on face, hair, etc. while working. & $65(32.5)$ & $113(56.5)$ & $22(11)$ & 0.00 & 62.17 \\
\hline 11.Must need tissue or cloth when coughing or sneezing. & $80(40)$ & $113(56.5)$ & $7(3.5)$ & 0.00 & 88.27 \\
\hline 12. Using mask is important in reducing risk of food contamination. & $76(38)$ & $115(57.5)$ & $9(4.5)$ & 0.00 & 86.23 \\
\hline 17. Foodborne illnesses can have deleterious health and economic effects on the society. & $69(34.5)$ & $119(59.5)$ & $12(6)$ & 0.00 & 85.99 \\
\hline $\begin{array}{l}\text { 18. Food hygiene training for workers is an important issue in reducing risk of food } \\
\text { contamination. }\end{array}$ & $78(39)$ & $107(53.5)$ & $15(7.5)$ & 0.00 & 66.37 \\
\hline 19. Well-cooked foods are free of contamination. & $82(41)$ & $88(44)$ & $30(15)$ & 0.00 & 30.52 \\
\hline $\begin{array}{l}\text { 20. Raw and cooked foods should be stored separately to reduce the risk of food } \\
\text { contamination. }\end{array}$ & $66(33)$ & $91(45.5)$ & $43(21.5)$ & 0.00 & 17.29 \\
\hline 21. Paper/polythene packs are unsafe for food packaging. & $64(32)$ & $81(40.5)$ & $55(27.5)$ & 0.07 & 5.23 \\
\hline
\end{tabular}

Note: $\mathrm{n}=$ Number of vendors, $\mathrm{p}=$ Significance value.

practice score of food safety achieved by any individual vendor were 30.43 and 63.04 respectively.

Figure 3 illustrates that there was a downward trend in food safety awareness, attitude and practice score of food handlers. The average knowledge and attitude score were much greater than that of practice. The KAP scores were converted to 100 points and the scores below $50 \%$ was accepted as poor, scores within 50 to $75 \%$ as moderate and the scores 75 to $100 \%$ as good. So, our obtained score of knowledge $(78.9 \pm 14.68)$ and attitude $(66.23 \pm 16.04)$ were categorized as good and moderate respectively, whereas, the practice scores $(46.40 \pm 7.06)$ lower than $50 \%$ was classified as poor.

Table 8 indicates the correlation between the different sociodemographic variables and KAP scores. Knowledge of food safety had a positive correlation with the level of education $(\mathrm{r}=0.33)$ and negative relation with smoking status $(r=-0.01)$. We found Significant positive correlation within education level and monthly income and food safety knowledge $\left(\mathrm{r}=0.14^{*}, \mathrm{r}=0.16^{*}\right.$, $\left.\mathrm{r}=00.38^{\star *}\right)$ and negative correlation of BMI $(\mathrm{r}=-0.08)$ with food safety attitude. Food safety practice had a positive relation with education level $\left(r=0.17^{\star}\right)$ and food safety knowledge $\left(\mathrm{r}=0.16^{\star}\right)$ and attitude $\left(\mathrm{r}=0.24^{\star *}\right)$, whereas smoking had no relation with hygiene practice. However, BMI had a negative relation with KAP score of vendors. Besides, vending experience in terms of years had significant negative relation $\left(\mathrm{r}=-0.01^{\star}\right)$ with food safety practice. Therefore, as attitudes and practice are positively correlated with knowledge, it can be anticipated that if knowledge level rises, attitude and practice will also improve.

\section{Discussion}

This present study provides the food safety KAP of the street food vendors in the Jashore region of Bangladesh. The mean scores of knowledge and practice of the vendors were $78.90 \pm$ 14.68 and $46.40 \pm 7.06$, respectively, showing Bangladeshi street food vendors' good knowledge and poor food handling practice in terms of food safety.

Many of the vendors in this sample were male (96\%). This contrasted with the results of similar studies in other countries like Brazil (Hanashiro et al., 2005); China (Ma et al., 2019); Nigeria (Omemu \& Aderoju, 2008) and Zimbabwe (Gadaga et al., 2008) where female were $56.6 \%, 66 \%, 78 \%$, and $81 \%$ respectively, but was congruent to the findings reported by previous two studies conducted in India where males were 70\% and 93.0\% (Bhowmik \& Saha, 2012; Singh et al., 2017; Thakur \& Singh, 2018). This can be explained by the fact that the lower proportion of women in Bangladesh are interested in food sales because they engage more in the traditional household and maternal roles (Asaduzzaman et al., 2015). Approximately the same number of vendors were living in rural (48\%) and urban (46\%) areas, not according to a study in Mohali, India where more street vendors (66\%) lived in rural areas (Singh et al., 2017). The majority of the vendors (70.5\%) were into a broader age range; 25 to 50 years old. This was strikingly similar to studies in Ghana (Monney et al., 2014) and India (Bhowmik \& Saha, 2012), with around $70 \%$ each of their vendors were also within this age range. Parallel social conditions may have existed behind this same age range of vendors in those countries. But not in accordance with the current study, a similar study conducted in Brazil 
Hossen et al.

Table 5. Effect of gender, age, education level, residence area, smoking and BMI on the food safety attitude of vendors.

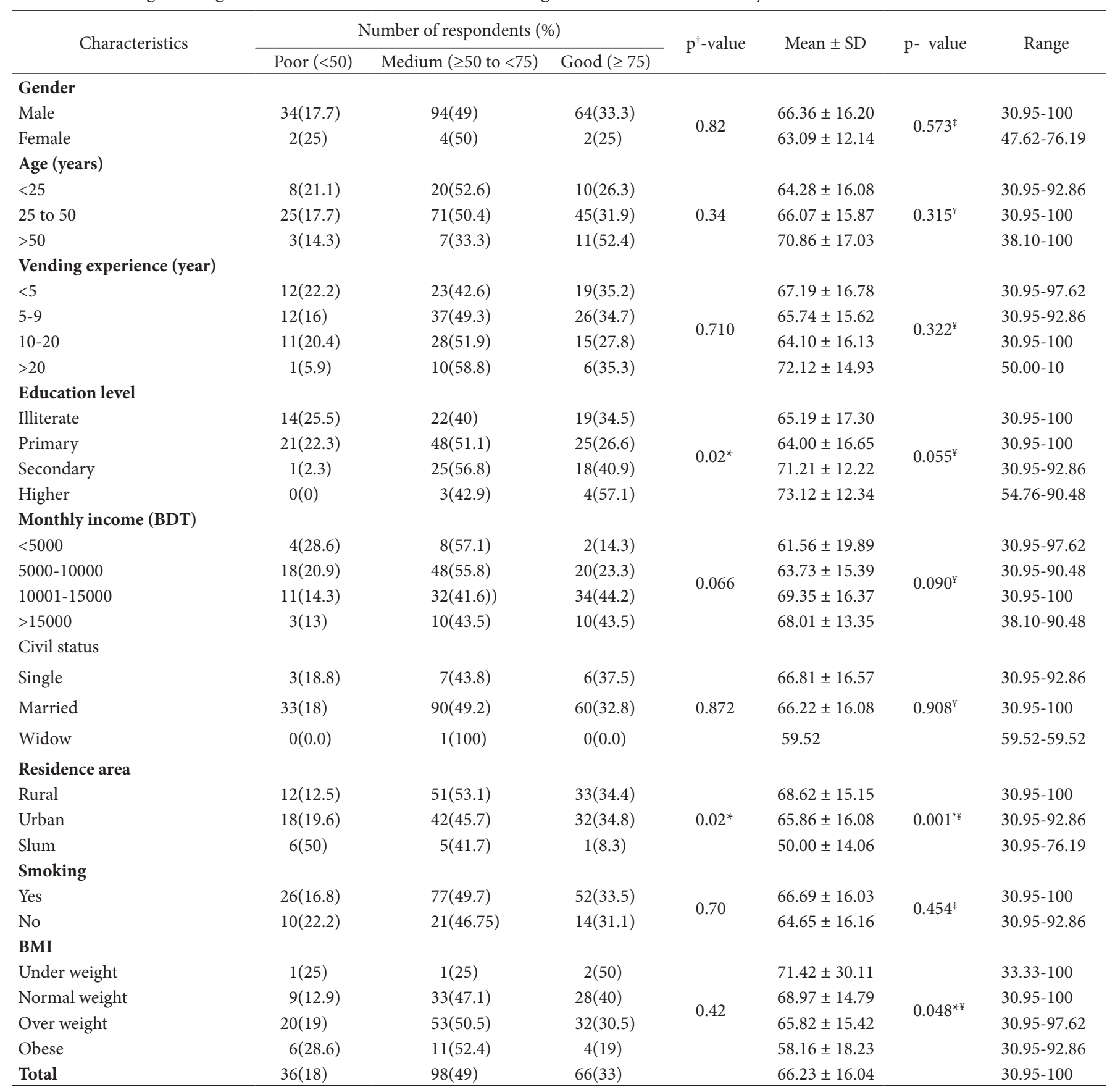

Note: $\mathrm{SD}=$ Standard deviation, $\mathrm{p}=$ Significance value, BMI = Body Mass Index, BDT = Bangladeshi Taka $\left(1\right.$ USD = 84.83 BDT); ${ }^{+}$Significance values by Chi-square test; ${ }^{*}$ Significance values by one-way ANOVA; "Significance values by independent sample " $\mathrm{t}$ " test; ${ }^{*}$ Tests significant at $\leq 0.05$.

reported that the majority of the vendors aged between 40 to 59 years (Cortese et al., 2016). In the current report, about $72 \%$ of vendors were smokers, while the proportion of smokers among ordinary Bangladeshis was only $36.3 \%$ (Nargis et al., 2015). In a related study in India, prevalence of smokers among street food vendors reported was 68.5\% (Kapoor et al., 2019). Nicotine and other harmful heavy metals will accumulate on the open food at the time of smoking by vendors, which can then present significant health risks to customers, such as coronary heart disease (Barnoya \& Glantz, 2004). To our surprise, significant numbers of vendors have been identified with abnormally obese body weight according to health status measurement by BMI. Overwhelmingly, $52.5 \%$ and about $10 \%$ of the vendors respectively were overweight and obese. Where in Bangladeshi people, $18.9 \%$ were overweight and $4.6 \%$ were obese (Biswas et al., 2017). This might be due to the physical inactivity noticed among vendors while selling foods. They most frequently sit on one position for a long time, regular intake of energy-dense fast foods away from home can often lead to their exceptionally high weight. A study in the UK reported that meal away from home 
Table 6. Assessment Food safety practice of street food vendors.

\begin{tabular}{|c|c|c|c|c|c|}
\hline Statement & $\begin{array}{c}\text { Always } \\
\mathrm{n}(\%)\end{array}$ & $\begin{array}{c}\text { Sometimes } \\
\mathrm{n}(\%)\end{array}$ & $\begin{array}{l}\text { Never } \\
\mathrm{n}(\%)\end{array}$ & $\begin{array}{c}\mathrm{p}- \\
\text { value }\end{array}$ & $\mathrm{Chi}^{2}$-value \\
\hline 1. Washing hands before processing food. & $172(86)$ & $28(14)$ & ------- & 0.00 & 103.68 \\
\hline 2. Washing hands before touching unwrapped raw foods. & 98(49) & $99(49.5)$ & $3(1.5)$ & 0.00 & 91.21 \\
\hline 3. Washing hands after touching unwrapped raw foods. & $100(50)$ & $67(33.5)$ & $33(16.5)$ & 0.00 & 33.67 \\
\hline 4. Using soaps/detergents to wash hands. & $139(69.5)$ & $60(30)$ & $1(0.5)$ & 0.00 & 143.83 \\
\hline $\begin{array}{l}\text { 5. Keeping your nails short and remove all adornments } \\
\text { before starting activities. }\end{array}$ & $108(54)$ & $83(41.5)$ & $9(4.5)$ & 0.00 & 79.51 \\
\hline 6. Washing hands after touching prepared foods. & $116(58)$ & $72(36)$ & $12(6)$ & 0.00 & 81.76 \\
\hline 7. Handling foods at work while having diarrhoea. & $9(4.5)$ & $40(20)$ & $151(75.5)$ & 0.00 & 167.23 \\
\hline 8. Cleaning the work area before starting work. & $145(72.5)$ & $45(22.5)$ & $10(5)$ & 0.00 & 147.25 \\
\hline 9. Washing hands after going to toilet. & $157(78.5)$ & $26(13)$ & $17(8.5)$ & 0.00 & 184.21 \\
\hline 10. Using apron at work daily. & $12(6)$ & $11(5.5)$ & $177(88.5)$ & 0.00 & 273.91 \\
\hline 11. Using mask at work daily. & $6(3)$ & $11(5.5)$ & 183(91.5) & 0.00 & 304.69 \\
\hline 12. Using cap at work daily. & $5(2.5)$ & $7(3.5)$ & $188(94)$ & 0.00 & 331.27 \\
\hline 13. Using gloves at work daily. & $6(3)$ & $5(2.5)$ & $189(94.5)$ & 0.00 & 336.73 \\
\hline 14. Washing hands before using gloves. & $5(2.5)$ & $7(3.5)$ & $188(94)$ & 0.00 & 331.27 \\
\hline 15. Washing and sanitizing the working clothes. & $22(11)$ & $67(33.5)$ & $111(55.5)$ & 0.00 & 59.41 \\
\hline 16. Using a tissue/cloth when coughing or sneezing. & $36(18)$ & $104(52)$ & $59(29.5)$ & 0.00 & 36.07 \\
\hline $\begin{array}{l}\text { 17. Washing and sanitizing the knife after chopping raw } \\
\text { chicken or meat or other raw food. }\end{array}$ & $96(48)$ & $100(50)$ & $4(2)$ & 0.00 & 88.48 \\
\hline 18. Using detergent to clean equipment. & $118(59)$ & $73(36.5)$ & $9(4.5)$ & 0.00 & 90.01 \\
\hline 19. Eating or drinking in the workplace. & $28(14)$ & $124(62)$ & $48(24)$ & 0.00 & 76.96 \\
\hline 20. Using jewelleries and wearing watch while working. & $13(6.5)$ & $73(36.5)$ & $114(57)$ & 0.00 & 77.41 \\
\hline 21. Rubbing hands on face, hair, etc. while working. & $26(13)$ & $89(44.5)$ & $85(42.5)$ & 0.00 & 37.33 \\
\hline 22. Smoking in workplace. & $8(4)$ & $69(34.5)$ & $123(61.5)$ & 0.00 & 99.31 \\
\hline 23. Reusing of oil. & $57(28.5)$ & $66(33)$ & $77(38.5)$ & 0.222 & 3.01 \\
\hline
\end{tabular}

Note: $\mathrm{n}=$ Number of vendors, $\mathrm{p}=$ Significance value.

is higher in fat and lower in fibre, which increases consumer's BMI (Rennie et al., 2005).

The mean \pm SD of knowledge score was $78.90 \pm 14.68$, which was comparably higher than street vendors surveyed in Malaysia (Toh \& Birchenough, 2000) and Turkey (Baş et al., 2006). We found that vendor's education has a major positive impact on their existing awareness about food hygiene, hence, vendors with a higher education status were found to have higher knowledge on food safety than those less qualified. A comparable research in Kuching Town, Malaysia, also noted the vital role of education level in awareness of food safety (Rahman et al., 2016). On the other hand, there were no significant differences in the street food vendors' level of awareness about food safety with regards to their gender and age in Jashore city. These findings are supported by previous studies in Malaysia (Muyanja et al., 2011) and Haiti (Samapundo et al., 2015). A research conducted in Canada found that age had a major effect on the awareness of food safety of food handlers (McIntyre et al., 2013). In our research, the age of food vending experience was not significantly linked to the vendor's awareness of food safety. However, this study found an acceptable knowledge level on food safety among the vendors studied.

99\% of food vendors claimed that proper handling of foods is an essential aspect of their job responsibilities. Where they all knew good personal hygiene would avoid customer's foodborne illness. Just a small proportion of the vendors (10.5\%) felt it was more important to prepare tasty food than to make healthy food.
This belief is in line with another study in the United Kingdom, where $97 \%$ of respondents thought it was necessary to produce healthy food than tasty food (Worsfold et al., 2004).

This study found significant variances in the food safety attitude of vendors according to their educational levels and vending locations. In slum areas, vendors had the worst food safety scores compared to those of urban and rural areas. The current study found that the majority of the vendors were less educated, maybe like other developing countries where educated individuals seek jobs in the capital city (Addo-Tham et al., 2020). However, with the increase in education level of the vendors, their food safety attitude improved. In Malaysia, there was also found a significant effect of education level on food safety attitudes of food handlers (Toh \& Birchenough, 2000). Education has been stated to play a key role in growing the awareness of food safety of food handlers and thereby improving their attitudes to food safety and hygiene (World Health Organization, 2015). As previously mentioned, a relatively more significant proportion of vendors were overweight and obese. Interestingly, with the decrease of BMI level, food safety attitude of vendors significantly improved in this study.

Furthermore, the self-reported hygiene practice showed that about $90 \%$ of the vendors in the present study did not use any personal protective equipment as well as safety procedures. The poor socio-economic condition with lacking proper food safety knowledge among the street food vendors is one of the potential reasons of their lower use of personal 
protective equipment (Gadaga et al., 2014). These findings were quite similar to the findings in Kenya (87.7\%) and contrast with the studies undertaken in Haiti and Uganda, where
$40 \%$ and $54 \%$ food vendor used personal hygiene (Muinde \& Kuria, 2005; Muyanja et al., 2011; Pincemail et al., 2012; Samapundo et al., 2016).

Table 7. Effect of gender, age, education level, residence area, smoking and BMI on the food safety practice of food vendors.

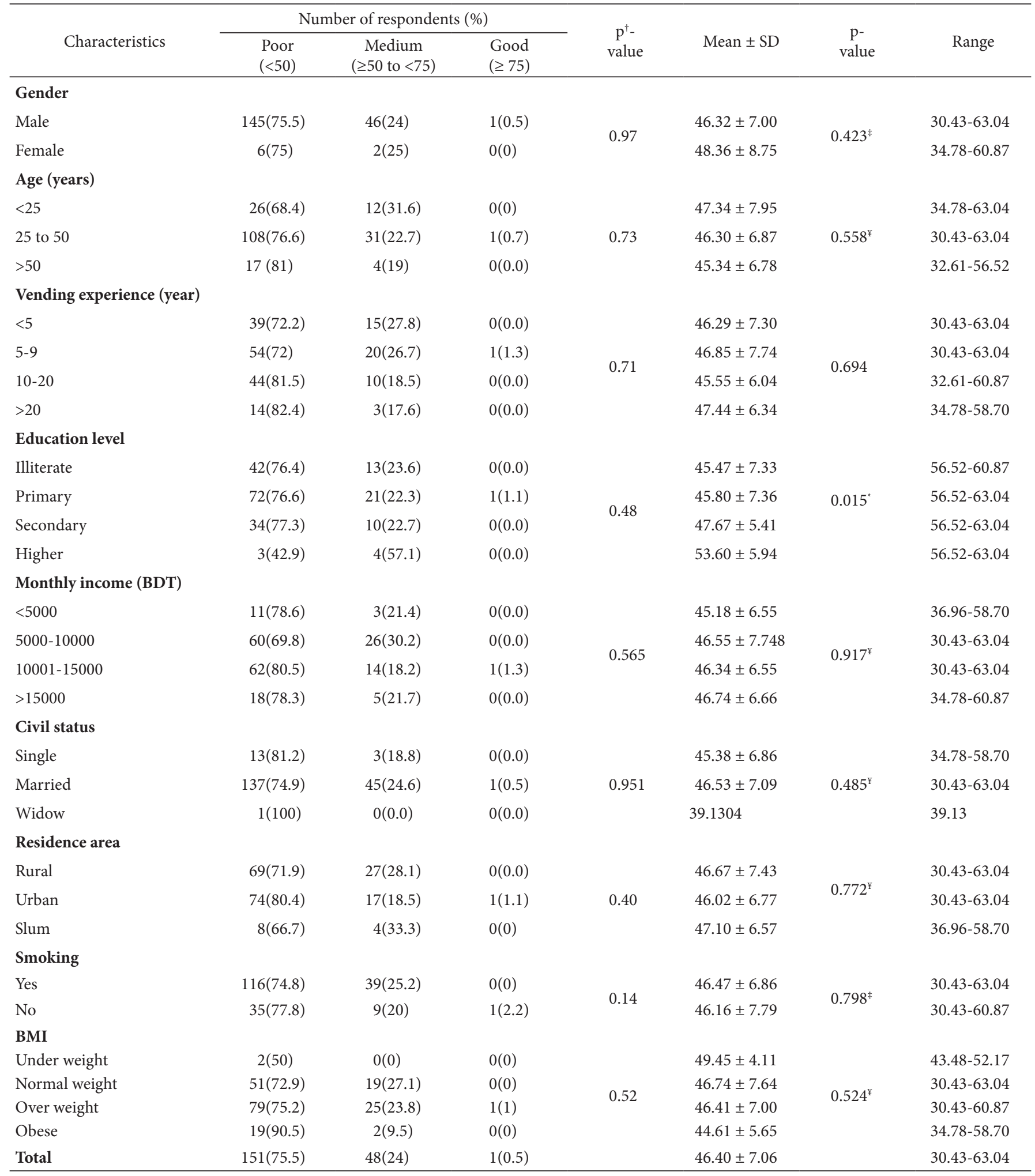

Note: $\mathrm{SD}=$ Standard deviation, $\mathrm{p}=$ Significance value, $\mathrm{BMI}=$ Body Mass Index; BDT = Bangladeshi Taka $(1 \mathrm{USD}=84.83 \mathrm{BDT})$; $†$ Significance values by Chi-square test; ${ }^{*}$ Significance values by one-way ANOVA; ${ }^{\ddagger}$ Significance values by independent sample " $t$ " test; ${ }^{*}$ Tests Significant at $\leq 0.05$. 
Table 8. The correlation between different socio-demographic variables and KAP score of food safety vendors.

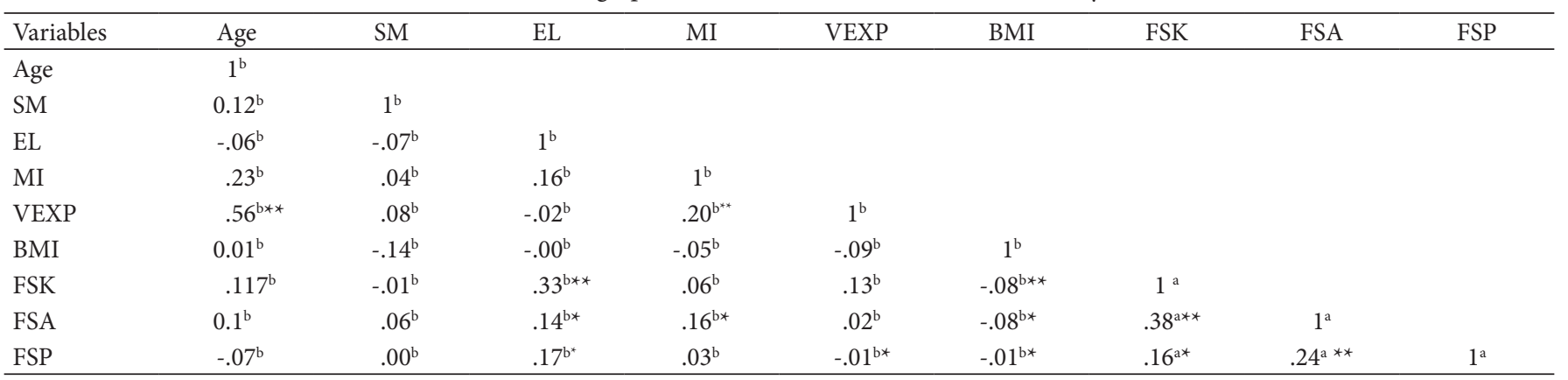

Note: $\mathrm{SM}=$ Smoking, EL = Education level, $\mathrm{MI}=$ Monthly Income, VEXP = Vending Experience, BMI = Body mass index, FSK = Food safety knowledge, FSA = Food safety attitude,

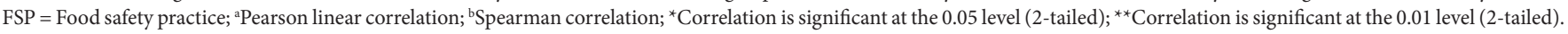

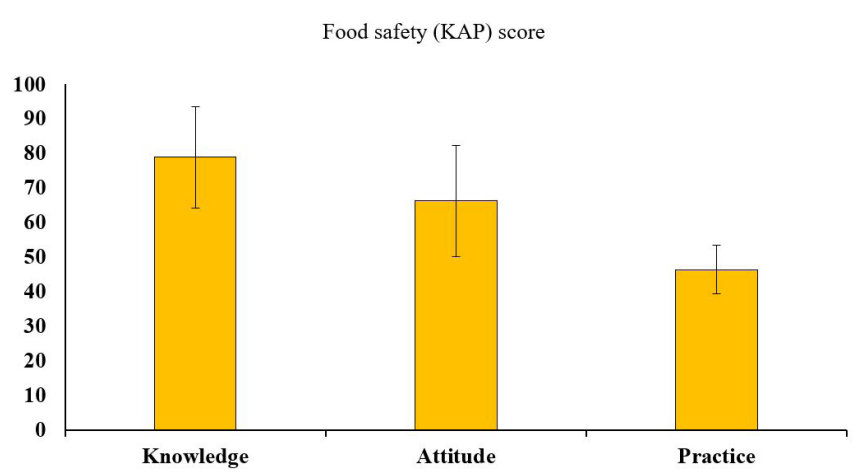

Figure 3. Food safety percent KAP score (mean \pm SD).

Unfortunately, the proportion of vendors belonging to good food safety practice level was negligible, $0.5 \%$. Around threefourths of food vendors were poorly trained when it came to food hygiene. Corresponding with our outcomes, a similar study conducted on the street food vendors in Vietnam revealed that vendors had poor food handling practices and operated foods under highly unhygienic conditions (Ngoc \& Thanh, 2015). However, this was slightly incongruous with earlier studies in Malaysia (Rahman et al., 2016) and Nigeria (Bamidele et al., 2015) where respondents had above $15 \%$ of good hygiene practice. Also, the length of the selling training was not directly related to their knowledge of food safety practices. We found that only the degree of education had a positive effect on their general practice of hygiene. On the contrary, a comparable study in Ghana reported that the food safety practice was not associated with the safety knowledge and education level of the vendors (Addo-Tham et al., 2020). We found that monthly income wasn't significant to their food safety and hygiene practice. But, another related study in Ethiopia showed that the increase of monthly income raised the level of food safety practice (Adane et al., 2018).

In the present analysis, each food safety parameter (KAPs) was positively associated with each other; the level of practice increased with an increased level of knowledge and attitude. Many earlier studies found that the level of awareness, attitude and food safety training were significantly related to the street food vendors' hygienic practices (Afolaranmi et al., 2015; Rahman et al., 2016; Tessema et al., 2014). In comparison, studies in Nigeria found that the attitude of food hygiene practices in vendors was not important (Otu, 2014), and another study in
Ghana reported that knowledge was not closely associated to hygiene practice which indicated that existing socio-cultural context might have a greater impact on food hygiene practices (Rheinländer et al., 2008).

From our observation, as food vendors have enough safety knowledge, they need to be encouraged in related food hygiene and safety practices. It was found that socio-economic conditions of food vendors have a significant influence on their food safety behaviour and hygienic practices, of which level of education was an important factor influencing their reaction towards food safety. So, education will make the system better counter towards the promotion of food hygiene. Nevertheless, vendors themselves should follow the food safety precautions at the time of food preparation, preservation, and serving food to the consumers.

In order to increase the current level of food safety and hygiene practice Government should impose safety policy on vendors and provide them proper training on food safety and hygiene (Liu et al., 2014). Establishment of safety tools such as risk assessment, HACCP, FSO (Food Safety Objective) is also an effective step towards improving food safety practices (Trafialek et al., 2018).

\section{Conclusion}

The study demonstrated that the level of food hygiene knowledge was satisfactory in food vendors of the studied area. Although the food vendors had adequate food safety knowledge and attitudes, they had a poor understanding of safe food handling, which was reflected in their largely inadequate facilities and unhygienic practices during the vending of the foods. Most street food vendors interviewed in this study had low educational levels, which significantly contributed to their poor food safety practices. The government should take necessary steps and impose suitable food hygiene rules and regulations to increase good food handling practices. This investigation provides data necessary for the development of policies and standards that will help to ensure the safety of street foods. Initiatives like the arrangement of training programs on standard food safety and hygiene practice for street food vendors can improve the overall safety of street foods and also reduce related public health risks among the consumers. 


\section{Acknowledgements}

We thank Monokesh Kumer Sen for some relevant suggestions and Daniel Ta for his efforts in correcting few grammatical mistakes in preparing this article.

\section{References}

Adane, M., Teka, B., Gismu, Y., Halefom, G., \& Ademe, M. (2018). Food hygiene and safety measures among food handlers in street food shops and food establishments of Dessie town, Ethiopia: a community-based cross-sectional study. PLoS One, 13(5), e0196919. http://dx.doi.org/10.1371/journal.pone.0196919. PMid:29723288.

Addo-Tham, R., Appiah-Brempong, E., Vampere, H., Acquah-Gyan, E., \& Gyimah Akwasi, A. (2020). Knowledge on food safety and food-handling practices of street food vendors in Ejisu-Juaben Municipality of Ghana. Advances in Public Health, 2020, 1-7. http:// dx.doi.org/10.1155/2020/4579573.

Afolaranmi, T. O., Hassan, Z. I., Bello, D. A., \& Misari, Z. (2015). Knowledge and practice of food safety and hygiene among food vendors in primary schools in Jos, Plateau State, North Central Nigeria. Journal of Medical Research, 4(2), 16-22.

Al Mamun, M., Rahman, S. M. M., \& Turin, T. C. (2013). Knowledge and awareness of children's food safety among school-based street food vendors in Dhaka, Bangladesh. Foodborne Pathogens and Disease, 10(4), 323-330. http://dx.doi.org/10.1089/fpd.2012.1283. PMid:23458028.

Anandhi, N., Janani, \& Krishnaveni, N. (2015). Microbiological quality of selected street-vended foods in Coimbatore, India. African Journal of Microbiological Research, 9(11), 757-762. http://dx.doi. org/10.5897/ajmr2013.6421.

Ansari-Lari, M., Soodbakhsh, S., \& Lakzadeh, L. (2010). Knowledge, attitudes and practices of workers on food hygienic practices in meat processing plants in Fars, Iran. Food Control, 21(3), 260-263. http://dx.doi.org/10.1016/j.foodcont.2009.06.003.

Asaduzzaman, M., Kabir, R. A., \& Radović-Marković, M. (2015). Gender inequality in Bangladesh. Journal of Women's Entrepreneurship and Education, 3-4, 54-64.

Atahar Ali, A. N. M. (2013). Food safety and public health issues in Bangladesh: a regulatory concern. European Food and Feed Law Review, 8(1), 31-40. https://www.jstor.org/stable/24325889.

Bamidele, J. O., Oladele, E. A., Adeoye, O. A., \& Adebimpe, W. O. (2015). Hygiene practices among workers in local eateries of Orolu community in south Western Nigeria. Annals of Medical and Health Sciences Research, 5(4), 235-240. http://dx.doi.org/10.4103/21419248.160176. PMid:26229710.

Bangladesh Bureau of Statistics - BBS. (2017). Bangladesh statistics 2017. Bangladesh: Bangladesh Bureau of Statistics, Statistics Informatics Division, Ministry of Planning.

Barnoya, J., \& Glantz, S. A. (2004). Secondhand smoke: the evidence of danger keeps growing. The American Journal of Medicine, 116(3), 201-202. http://dx.doi.org/10.1016/j.amjmed.2003.11.005. PMid:14749167.

Baş, M., Şafak Ersun, A., \& Kıvanç, G. (2006). The evaluation of food hygiene knowledge, attitudes, and practices of food handlers' in food businesses in Turkey. Food Control, 17(4), 317-322. http://dx.doi. org/10.1016/j.foodcont.2004.11.006.

Bhattacharjya, H., \& Reang, T. (2014). Safety of street foods in Agartala, North East India. Public Health, 128(8), 746-748. https://doi. org/10.1016/j.puhe.2014.05.013.
Bhowmik, S. K., \& Saha, D. (2012). Street vending in ten cities in India. New Delhi: Delhi National Association of Street Vendors of India.

Biswas, T., Garnett, S. P., Pervin, S., \& Rawal, L. B. (2017). The prevalence of underweight, overweight and obesity in Bangladeshi adults: Data from a national survey. PLoS One, 12(5), e0177395. http://dx.doi. org/10.1371/journal.pone.0177395. PMid:28510585.

Bryan, F. L. (1988). Risks of practices, procedures and processes that lead to outbreaks of foodborne diseases. Journal of Food Protection, 51(8), 663-673. http://dx.doi.org/10.4315/0362028x-51.8.663.

Cortese, R. D. M., Veiros, M. B., Feldman, C., \& Cavalli, S. B. (2016). Food safety and hygiene practices of vendors during the chain of street food production in Florianopolis, Brazil: a cross-sectional study. Food Control, 62, 178-186. http://dx.doi.org/10.1016/j. foodcont.2015.10.027.

Ekanem, E. O. (1998). The street food trade in Africa: safety and socioenvironmental issues. Food Control, 9(4), 211-215. http://dx.doi. org/10.1016/S0956-7135(97)00085-6.

Fellows, P., \& Hilmi, M. (2011). Selling street and snack foods. In Food and Agriculture Organization of the United Nations - FAO. FAO diversification booklet (Vol. 18). Rome: FAO.

Food and Agriculture Organization of the United Nations - FAO \& World Health Organization - WHO. (2003). Assuring food safety and quality: guidelines for strengthening national food control systems. Rome: FAO.

Food and Agriculture Organization of the United Nations - FAO. (2007). Crop prospects and food situation: global cereal production brief (No. 4). Rome: FAO.

Food and Agriculture Organization of the United Nations - FAO. (2013). The state of food insecurity in the world: the multiple dimensions of food security. Rome: FAO.

Gadaga, T. H., Samende, B. K., Musuna, C., \& Chibanda, D. (2008). The microbiological quality of informally vended foods in Harare, Zimbabwe. Food Control, 19(8), 829-832. http://dx.doi.org/10.1016/j. foodcont.2007.07.016.

Gadaga, T., Ntsike, M., \& Ntuli, V. (2014). Socio-economic and hygienic aspects of street food vending in Maseru City, Lesotho. USWA Research Journal of Agriculture, Science and Technology, 5, 28-39.

Gamieldien, F., \& van Niekerk, L. (2017). Street vending in South Africa: an entrepreneurial occupation. South African Journal of Occupational Therapy, 47(1), 24-29. http://dx.doi.org/10.17159/2310-3833/2017/ vol47n1a5.

Ghosh, M., Wahi, S., Kumar, M., \& Ganguli, A. (2007). Prevalence of enterotoxigenic Staphylococcus aureus and Shigella spp. in some raw street vended Indian foods. International Journal of Environmental Health Research, 17(2), 151-156. http://dx.doi. org/10.1080/09603120701219204. PMid:17616871.

Guven, K., Mutlu, M. B., Gulbandilar, A., \& Cakir, P. (2010). Occurrence and characterization of staphylococcus aureus isolated from meat and dairy products consumed in Turkey. Journal of Food Safety, 30(1), 196-212. http://dx.doi.org/10.1111/j.17454565.2009.00200.x.

Hanashiro, A., Morita, M., Matté, G. R., Matté, M. H., \& Torres, E. A. F. S. (2005). Microbiological quality of selected street foods from a restricted area of São Paulo City, Brazil. Food Control, 16(5), 439444. http://dx.doi.org/10.1016/j.foodcont.2004.05.004.

Harakeh, S., Yassine, H., Gharios, M., Barbour, E., Hajjar, S., El-Fadel, M., Toufeili, I., \& Tannous, R. (2005). Isolation, molecular characterization and antimicrobial resistance patterns of Salmonella and Escherichia 
coli isolates from meat-based fast food in Lebanon. The Science of the Total Environment, 341(1-3), 33-44. http://dx.doi.org/10.1016/j. scitotenv.2004.09.025. PMid:15833239.

Hiamey, S. E., \& Hiamey, G. A. (2018). Street food consumption in a Ghanaian Metropolis: The concerns determining consumption and non-consumption. Food Control, 92, 121-127. http://dx.doi. org/10.1016/j.foodcont.2018.04.034.

Hossain, M., \& Dey, B. K. (2019). Microbial contamination of handmade sauce used by street food vendors in Jashore, Bangladesh. Journal of Food Quality and Hazards Control, 6(3), 115-120. https://doi. org/10.18502/jfqhc.6.3.1385.

Islam, N., Arefin, Md. Shamsul, Nigar, T., Haque, S. N., Haq, K. I., Emran, Md. T. A., \& Nazrul, T. (2017). Street food eating habits in Bangladesh: a study on Dhaka city. Int. Journal of Management and Development Studies, 6(9), 49-57.

Kapoor, S., Mohanty, V., \& Balappanavar, A. Y. (2019). Tobacco use: Exploring the beliefs of street food vendors in Delhi, India. Journal of Indian Association of Public Health Dentistry, 17(1), 14. http:// dx.doi.org/10.4103/jiaphd.jiaphd_208_18.

Khairuzzaman, M., Chowdhury, F. M., Zaman, S., Al Mamun, A., \& Bari, M. L. (2014). Food safety challenges towards safe, healthy, and nutritious street foods in Bangladesh. International Journal of Food Science, 2014, 1-9. http://dx.doi.org/10.1155/2014/483519.

King, L. K., Awumbila, B., Canacoo, E. A., \& Ofosu-Amaah, S. (2000). An assessment of the safety of street foods in the Ga district, of Ghana; Implications for the spread of zoonoses. Acta Tropica, 76(1), 39-43. http://dx.doi.org/10.1016/S0001-706X(00)00087-5. PMid:10913764.

König, A., Kuiper, H. A., Marvin, H. J. P., Boon, P. E., Busk, L., Cnudde, F., Cope, S., Davies, H. V., Dreyer, M., Frewer, L. J., Kaiser, M., Kleter, G. A., Knudsen, I., Pascal, G., Prandini, A., Renn, O., Smith, M. R., Traill, B. W., \& van der Voet, H., vanTrijp, H., Vos, E., \& Wentholt, M. T. A. (2010). The SAFE FOODS framework for improved risk analysis of foods. Food Control, 21(12), 1566-1587. http://dx.doi. org/10.1016/j.foodcont.2010.02.012.

Liu, Z., Zhang, G., \& Zhang, X. (2014). Urban street foods in Shijiazhuang city, China: Current status, safety practices and risk mitigating strategies. Food Control, 41, 212-218. http://dx.doi.org/10.1016/j. foodcont.2014.01.027.

Lucca, A., \& Torres, E. A. F. S. (2006). Street-food: the hygiene conditions of hot-dogs sold in São Paulo, Brazil. Food Control, 17(4), 312-316. http://dx.doi.org/10.1016/j.foodcont.2004.11.005.

Lues, J. F. R., Rasephei, M. R., Venter, P., \& Theron, M. M. (2006). Assessing food safety and associated food handling practices in street food vending. International Journal of Environmental Health Research, 16(5), 319-328. http://dx.doi.org/10.1080/09603120600869141. PMid:16990173.

Ma, L., Chen, H., Yan, H., Wu, L., \& Zhang, W. (2019). Food safety knowledge, attitudes, and behavior of street food vendors and consumers in Handan, a third tier city in China. BMC Public Health, 19(1), 1128. http://dx.doi.org/10.1186/s12889-019-7475-9. PMid:31419983.

Maps of Bangladesh. Jashore (2012). Retrieved from http://maps-ofbangladesh.blogspot.com/search/label/Jessore

McIntyre, L., Vallaster, L., Wilcott, L., Henderson, S. B., \& Kosatsky, T. (2013). Evaluation of food safety knowledge, attitudes and self-reported hand washing practices in FOODSAFE trained and untrained food handlers in British Columbia, Canada. Food Control, 30(1), 150-156. http://dx.doi.org/10.1016/j.foodcont.2012.06.034.

Monney, I., Agyei, D., Ewoenam, B. S., Priscilla, C., \& Nyaw, S. (2014). Food hygiene and safety practices among street food vendors: an assessment of compliance, institutional and legislative framework in Ghana. Food and Public Heath, 4(6), 306-315. http://dx.doi. org/10.5923/j.fph.20140406.08.

Muinde, O. K., \& Kuria, E. (2005). Hygienic and sanitary practices of vendors of street foods in Nairobi Kenya. African Journal of Food, Agriculture, Nutrition and Development, 5(1), 1-14.

Muyanja, C., Nayiga, L., Brenda, N., \& Nasinyama, G. (2011). Practices, knowledge and risk factors of street food vendors in Uganda. Food Control, 22(10), 1551-1558. http://dx.doi.org/10.1016/j. foodcont.2011.01.016.

Nargis, N., Thompson, M. E., Fong, G. T., Driezen, P., Hussain, A. K., Ruthbah, U. H., Quah, A. C., \& Abdullah, A. S. (2015). Prevalence and patterns of tobacco use in Bangladesh from 2009 to 2012: evidence from International Tobacco Control (ITC) Study. PLoS One, 10(11), e0141135. http://dx.doi.org/10.1371/journal.pone.0141135. PMid:26559051.

Ngoc, T., \& Thanh, C. (2015). Food safety behavior, attitudes and practices of street food vendors and consumers in Vietnam (Master's dissertation). Faculty of Bioscience Engineering, Universiteit Gent, Bélgica.

Ngoc, T., Thanh, C., Reviewers, P., Iwu, A. C., Uwakwe, K. A., Duru, C. B., Diwe, K. C., Chineke, H. N., Merenu, I. A., Oluoha, U. R., Madubueze, U. C., Ndukwu, E., Ohale, I., Soon, J. A. N. M. E. I., Baines, R., Seaman, P., Infections, I., Malliarou, M., Kudavidnange, B. P., \& Kosatsky, T. (2011). Assessing the knowledge, attitudes and practices of street food vendors in the city of johannesburg regarding food hygiene and safety. Food Control, 30, 150-156.

Oguttu, J. W., McCrindle, C. M., Makita, K., \& Grace, D. (2014). Investigation of the food value chain of ready-to-eat chicken and the associated risk for staphylococcal food poisoning in Tshwane Metropole, South Africa. Food Control, 45, 87-94. http://dx.doi. org/10.1016/j.foodcont.2014.04.026.

Omemu, A. M., \& Aderoju, S. T. (2008). Food safety knowledge and practices of street food vendors in the city of Abeokuta, Nigeria. Food Control, 19(4), 396-402. http://dx.doi.org/10.1016/j. foodcont.2007.04.021.

Otu, S. S. (2014). Food Hygiene Practices Among Food Handlers in Ahmadu Bello University (A.B.U.), Zaria. Zaria: Ahmadu Bello University.

Pincemail, J., Kevers, C., Tabart, J., Defraigne, J. O., \& Dommes, J. (2012). Cultivars, culture conditions, and harvest time influence phenolic and ascorbic acid contents and antioxidant capacity of strawberry (Fragaria x ananassa). Journal of Food Science, 77(2), C205-C210. http://dx.doi.org/10.1111/j.1750-3841.2011.02539.x. PMid:22251305.

Rahman, M. M., Arif, M. T., Bakar, K., \& Tambi, Z. (2016). Food safety knowledge, attitude and hygiene practices among the street food vendors in Northern Kuching City, Sarawak. Borneo Science, 31, 95-103.

Rennie, K. L., Johnson, L., \& Jebb, S. A. (2005). Behavioural determinants of obesity. Best Practice \& Research. Clinical Endocrinology \& Metabolism, 19(3), 343-358. http://dx.doi.org/10.1016/j.beem.2005.04.003. PMid:16150379.

Rheinländer, T., Olsen, M., Bakang, J. A., Takyi, H., Konradsen, F., \& Samuelsen, H. (2008). Keeping up appearances: Perceptions of street food safety in urban Kumasi, Ghana. Journal of Urban Health, 85(6), 952-964. http://dx.doi.org/10.1007/s11524-008-9318-3. PMid:18821020.

Samapundo, S., Cam Thanh, T. N., Xhaferi, R., \& Devlieghere, F. (2016). Food safety knowledge, attitudes and practices of street food vendors and consumers in Ho Chi Minh city, Vietnam. Food Control, 70, 79-89. http://dx.doi.org/10.1016/j. foodcont.2016.05.037. 
Samapundo, S., Climat, R., Xhaferi, R., \& Devlieghere, F. (2015). Food safety knowledge, attitudes and practices of street food vendors and consumers in Port-au-Prince, Haiti. Food Control, 50, 457-466. http://dx.doi.org/10.1016/j.foodcont.2014.09.010.

Sharma, I., \& Mazumdar, J. A. (2014). Assessment of bacteriological quality of ready to eat food vended in streets of Silchar city, Assam, India. Indian Journal of Medical Microbiology, 32(2), 169-171. http:// dx.doi.org/10.4103/0255-0857.129809. PMid:24713905.

Singh, C., Singh, H., Singh, H., Singh, B., Singh, N., Youdon, T., Kaur, H., \& Marwaha, S. (2017). Assessing the hygiene practices among street food vendors in Mohali. The International Journal of Indian Psychology, 5(1). https://doi.org/ 10.25215/0501.027.

Temeche, M., Satheesh, N.,\& Tolera, K. D. (2016). Food safety knowledge, practice and attitude of food handlers in traditional Hotels of Jimma Town, Southern Ethiopia. Annals. Food Science and Technology, 17, 507-517.

Tessema, A. G., Gelaye, K. A., \& Chercos, D. H. (2014). Factors affecting food handling Practices among food handlers of Dangila town food and drink establishments, North West Ethiopia. BMC Public Health, 14(1), 571. http://dx.doi.org/10.1186/1471-2458-14-571. PMid:24908104.

Thakur, A. T., \& Singh, U. (2018). A study on sanitation, hygiene practices and food safety knowledge among food vendors in different sectors of Chandigarh, India. Journal of Applied and Natural Science, 10(3), 931-934. http://dx.doi.org/10.31018/jans.v10i3.1860.

Toh, P. S., \& Birchenough, A. (2000). Food safety knowledge and attitudes: culture and environment impact on hawkers in Malaysia: Knowledge and attitudes are key attributes of concern in hawker foodhandling practices and outbreaks of food poisoning and their prevention. Food Control, 11(6), 447-452. http://dx.doi.org/10.1016/ S0956-7135(00)00008-6.

Trafialek, J., Drosinos, E. H., Laskowski, W., Jakubowska-Gawlik, K., Tzamalis, P., Leksawasdi, N., Surawang, S., \& Kolanowski, W. (2018). Street food vendors' hygienic practices in some Asian and EU countries - A survey. Food Control, 85, 212-222. http://dx.doi. org/10.1016/j.foodcont.2017.09.030.

Webb, M., \& Morancie, A. (2015). Food safety knowledge of foodservice workers at a university campus by education level, experience, and food safety training. Food Control, 50, 259-264. http://dx.doi. org/10.1016/j.foodcont.2014.09.002.

Winarno, F. G., \& Alain, A. (1991). Street foods in developing countries: lessons from Asia. Rome: FAO.

World Health Organization - WHO. (2004). Appropriate body-mass index for Asian populations and its implications for policy and intervention strategies: report of a WHO expert consultation. Geneva: WHO.

World Health Organization - WHO. (2014). WHO initiative to estimate the global burden of foodborne diseases: fourth formal meeting of the Foodborne Disease Burden Epidemiology Reference Group (FERG): sharing new results, making future plans, and preparing ground for the countries. Geneva: WHO.

World Health Organization - WHO. (2015). World Health Day 2015: food safety. improving food safety, from farm to plate. Geneva: WHO.

Worsfold, D., Worsfold, P. M., \& Griffith, C. J. (2004). An assessment of food hygiene and safety at farmers' markets. International Journal of Environmental Health Research, 14(2), 109-119. http://dx.doi.org /10.1080/0960312042000209507. PMid:15203456. 